\title{
The Effect of Organizational Culture and Leadership Style on Employees at Radio Televisao de Timor Leste. Empresa Publico (RTTL.EP), Timor-Leste
}

\author{
Januario Soares ${ }^{1}$, Dian Indiyati ${ }^{2}$, Astri Ghina ${ }^{3}$ \\ ${ }^{12,3}$ Faculty of Economic and Business, Telkom University, Indonesia \\ Email: januariosoares7@gmail.com
}

\begin{abstract}
Organizational culture and leadership are part of human resources which are one of the capital and have a very important role for the success of a company or organization because good human resource management is the key to the successful achievement of the company's goals. The success of an organization in achieving its goals in addition to requiring a good organizational culture, also depends on the implementation of the leadership style. A strong leadership style in the organization is used to direct all available resources in achieving goals and optimizing success in a company. This study aims to determine to test and analyze the influence of Organizational Culture and Transformational Leadership Style on Employee Performance at RTTL.EP. The aspects studied are the employee's work culture, the leadership style of a leader, and the impact of the process of the two variables which will result in employee job performance. The phenomenon in this research is explored with quantitative methods. Data collection techniques are by distributing research questionnaires, interviews, and collecting secondary data. The sample taken was 180 samples of RTTL.EP employees. The results of this study are expected to be used as a work evaluation to improve organizational culture, leadership, and performance, this research can be used as a direction in improving employee performance at RTTL.EP so that it is always in line with the Vision and Mission of RTTL.EP, which is to provide quality programs to the audience.
\end{abstract}

Keywords: Human Resources, Organizational Culture, Leadership Style, Employee Performance.

\section{A. INTRODUCTION}

Organizational culture is part of human resources, which is one of the capital and has a vital role in a company's success. Good human resource management is the key to achieving company goals (Schein, 1990). Because organizational culture will according to Behery et al. (2014), "organizational culture is formed from an early phase in the life of any organization" it is concluded that the organizational culture of a company is a reflection of the organization, therefore to achieve organizational goals that have good performance requires cooperation from various parties. And the performance of an organization is often judged by its organizational culture because the organization's culture, as already described right above, reflects the organization itself. Furthermore, it can be said that an organization that is reflected in an excellent organizational culture will depend on its leadership style. According to Behery et al. (2014), "Organizational culture presents itself as both an organizational strength and a barrier to development". 
Organizational culture can influence how people set personal and professional goals, perform tasks, and manage resources to achieve them. Organizational culture affects how people consciously and unconsciously think, make decisions, and ultimately the way they perceive, feel, and act. The effect can vary between increasing efficiency and performance and inhibiting the workflow process (Alvesson, 2012).

According to Robbins et al. (2013), a company's organizational culture is believed to be very important. "If the culture is strong and supports high ethical standards, it should have a potent and positive influence on employee behavior." Besides the importance of organizational values in influencing individual behavior and traits. That's because the relationship between the person-organization fit with the level of job satisfaction, commitment, and turnover of employees, in which individuals are following the organization's culture tends to job satisfaction and commitment to the organization and have a high intensity to continue to work/stay organized (Robbins et al., 2013).

Meanwhile, individuals who are not following the organizational culture will tend to have job satisfaction and low commitment to the organization and tend to leave the organization (Sutrisno, 2019). So it is concluded that "organizational culture is truly managed as a management tool that will have an effect and become a motivation for employees to behave positively, dedicated and productively" (Sutrisno, 2019 ). Therefore organizational culture deserves to be studied based on the demand and urgency of organizations that are facing this gap so that it will be able to change the habits of employees at work to achieve the goals that have been implemented by the organization (Linnenluecke \& Griffiths, 2010).

Human resources in the company need to be managed professionally to balance the needs of employees and the demands and capabilities of the company organization. This balance is the primary key for the company to develop productively and legally; the development of business and company organization is highly dependent on its workforce's productivity. With professional human resource management arrangements, companies are expected to work productively (Oktania, 2014).

RTTL.EP is a state-owned enterprise (Hereafter known as BUMN) company engaged in the radio and television industry in Timor-Leste and employs approximately 180 employees. The State-Owned Enterprise (BUMN) itself is a business entity that is partly or wholly owned by the state of Timor-Leste. RTTL.EP, which is domiciled in Dili, is the Head Office in Timor-Leste, as a company that provides various news and various other events for the people of Timor-Leste and always tries its best to have an organization that is culturally very good to meet the needs and demands the audience of events through RTTL.EP.

Organization Culture is needed in RTTL.EP is based on need and urgency. Besides, according to O'Reilly et al. (in Sutrisno, 2019) states that "the suitability of individuals with organizational culture can predict increased performance, 
satisfaction and workforce turnover for various positions." Based on the above theories, it is why organizational culture needs to be studied at RTTL.EP.

This study aims to determine to test and analyze the influence of Organizational Culture and Transformational Leadership Style on Employee Performance at RTTL.EP. The aspects studied are the employee's work culture, the leadership style of a leader, and the impact of the process of the two variables which will result in employee job performance.

\section{B. LITERATURE REVIEW}

\section{Organizational Culture}

Organizational culture is a series of principle systems that are jointly recognized and applied by all organization elements. This is the difference between one organization and another. The definition of organizational culture is how an organization interacts with an integrated environment, both behavior, assumptions, stories, ideas, myths, and thoughts that emphasize the meaning of working in an organization (Sutrisno, 2010).

Organizational culture is a basic set of assumptions. These assumptions then develop in a group to become a reference for behavior in the organization. This habit will be passed on to future generations as a perspective, based on action in organizations (Indiyati, 2014).

Organizational culture is fundamental, which contains beliefs and shared core values, which is a core characteristic, which is believed and carried out by all organization members. Organizational culture reflects the general perception carried out by all organizations

Organizational culture is an important aspect that needs a close attention, because it reflects the characteristics and the image of the organization. If the organisation has the characteristics of organizational cultural values shared by all members of the organisation, it can be said to have a strong organizational culture more ever in (Indiyati, 2018). Organizational culture is regarded as a collective thought process and a thorough understanding of all members of the organisation about what and how each employee can achieve organizational objectives.

Robbins (2013), describes organizational culture as a general perception held by organizational members, a shared meaning system. Organizational culture is concerned with how workers perceive an organizational culture's characteristics, not what they are like. Meanwhile, according to Kreitner and Kinicki (2008), organizational culture is the shared values and beliefs underlying corporate identity.

Indiyati $(2014,2018)$, provides an understanding of organizational culture as a collective belief system that people in the organization have about their ability to compete in the market and how they act in this belief system to provide added value to products and services in the market (customers) in return for financial rewards. Organizational culture is expressed through the attitudes, systems, beliefs, dreams, behavior, values, procedures of the company, and primarily through the actions and performance of employees and management. 
Concerning the social aspect, culture functions as a social glue that helps unite the organization by providing proper standards for what employees have to say and do. In the end, culture functions as a meaning-making and control mechanism that guides and shapes attitudes. And the behavior of employees (Meek, 1988).

A cohesion or effective organizational culture is reflected in trust, openness, communication, leadership that gets input and is supported by subordinates, problem solvers by groups, work independence, and information exchange. Therefore, these employees must be appropriately managed employees that the organization in achieving the goals of the organization that have been determined. Based on this description, it can be concluded that the primary purpose of human resources is to increase the contribution of human resources or employees to the organization concerned (Ojo, 2009).

\section{Employee Performance}

Performance is a noun. One of its essential meanings is "thing is done" (something that has been done). So the meaning of performance is the result of work that can be achieved by a person or group of people in an organization, following their respective authorities and responsibilities to achieve the goals of the organization concerned legally, does not violate the law and is following morals or ethics (Rahadi, 2010).

Performance is a person's overall results during a specific period in carrying out tasks, such as work standards, targets, or criteria that have been determined in advance and have been mutually agreed (Rivai \& Basri, 2004). Suppose it is related to performance as a noun. In that case, the meaning of performance is the work that can be achieved by a person or group of people in a company following their respective authorities and responsibilities to achieve company goals legally, not violating the law and does not conflict with morals and ethics (Rivai \& Basri, 2004).

Based on multiple expert opinions can be concluded that the performance appraisal system is the process of measuring employee performance based on the rules that have been established, by way of comparing the target (of his work) with the requirements of the job description is a definitive work that has been found for a certain period. These work standards can be made both qualitatively and quantitatively.

\section{Leadership Style}

Leadership style is a leader's behavior in carrying out various leadership functions and is influenced by multiple factors, including education, experience, personality, and situational. According to Greenberg \& Baron (2000), "Leadership is a process by which individual influences other group members towards achieving defined group or organizational goals". 
Meanwhile, according to House et al. (2015) "Leadership is the ability of certain individuals to influence, motivate and enable others to contribute to organizational effectiveness and success." According to Colquitt, LePie, \& Wesson (2018), leadership is the use of power and influence to target follower activities to achieve goals, where direction can influence followers' interpretation of events, the organization of events, the organization of their work activities, their commitment to goals. Primary, their relationship with other followers, and their access to cooperation and support from other work units.

\section{Transformational Leadership}

Burns (in Yukl, 2008), defines transformational leadership as a process to achieve collective goals through the union of mutually beneficial motives that the leader and subordinates have to achieve the desired change. A transformational leadership style is a leader who inspires followers to go beyond their interests and can have a profound and profound impact on the person of their followers. (Ansory et al., 2018). Transformational leadership is a process whereby a leader is concerned about the concerns and needs of individual followers; these leaders change followers' awareness of problems by helping them see old problems in new ways, and they inspire and inspire followers to make extra efforts to achieve group goals.

\section{METHOD}

Based on this study's objectives, yes, it is knowing the influence of culture on employee performance so that the type of research used is quantitative. Quantitative research is research in the form of numbers and analysis using statistics. Based on the relationship between the variables, namely the relationship between cultural variables and employee performance, this research is causal or causal research. The study, according to Indrāvati (2015), is research conducted if the research wants to describe the cause of a problem (either through experiment or non- experiment). Suliyanto (2006), explains that quantitative research is research based on quantitative data in which quantitative data is data in the form of numbers or numbers.

The data was obtained based on the results of field data collection which was carried out from June 1 to 26, 2020 for 124 employees through face-to-face meetings with respondents and virtually, namely by sharing the questionnaire link through the google form application to be filled in by employees who were research respondents. The research location is at the RTTL.EP Office, Estrada Mercado Municipal Caicoli, Dili City, Timor Leste. Based on the data recapitulation results, all respondents (124 employees) have filled in and returned the questionnaire, so this research was conducted on 124 employees of RTTL.EP. 


\section{RESULT AND DISCUSSION}

\section{Organizational Culture}

Organizational culture is a component in a fundamental and essential organizational system. Although abstract and general, organizational culture guides corporate strategy, interactions between people, and governs how to work to achieve goals. Robbins (2013), describes organizational culture as a system of values and a vision that is agreed upon and held by all members of the organization, which determines how and the working mechanism of each member of the organization. Every company has its own organizational culture that is its hallmark and excellence; without an organizational culture, a company will find it challenging to grow and develop.

Organizational Culture variables are measured from 7 (seven) dimensions, namely Innovation and Courage to Take Risks, Attention to Details, ResultsOriented, Human-Oriented, Team Oriented, and Aggressive Stability as measured by 20 statement indicators Based on the descriptive data exposure of the respondent's response to each dimension, it can be seen in general that the respondent's assessment of the Organizational Culture variable can be seen from the presentation of the data processing results in table 4.1 below:

Table 1 Recapitulation of Respondents' Responses to Organizational Culture Variables

\begin{tabular}{|c|l|c|c|c|}
\hline No & \multicolumn{1}{|c|}{ Dimensions } & Score & Percentage & Category \\
\hline 1 & Innovation and the courage to take risks & 1265 & $68.01 \%$ & Strong \\
\hline 2 & Attention to detail & 1359 & $73.06 \%$ & Strong \\
\hline 3 & Result oriented & 1237 & $66.51 \%$ & Enough \\
\hline 4 & Oriented to humans & 1231 & $66.18 \%$ & Enough \\
\hline 5 & Team oriented & 1109 & $59.62 \%$ & Enough \\
\hline 6 & Aggressive attitude & 1095 & $58.87 \%$ & Enough \\
\hline 7 & Stability & 729 & $58.79 \%$ & Enough \\
\hline \multicolumn{2}{r|}{ Total } & $\mathbf{8 0 2 5}$ & $\mathbf{6 4 . 7 2 \%}$ & Strong \\
\hline
\end{tabular}

Source: Questionnaire Data Processing, 2020

The data displayed in table 4.8 shows that the dimension of Organizational Culture that is perceived by the respondent the highest is attention to detail (the percentage reaches $73.06 \%$ or is in the Strong category). Next is the dimensions of innovation and courage to take risks $(68.01 \%)$, results-oriented $(66.51 \%)$, humanoriented $(66.18 \%)$, team-oriented $(59.62 \%)$, aggressive $(58.87 \%)$, while the lowest dimension was stability $(58.79 \%)$.

These results indicate that the overall implementation of organizational culture in the RTTL.EP is in the sufficient category, meaning that the company does not fully have a mutually agreed value system and rules to serve as a guide in achieving the general goals of the organization, running programs, and social interactions at all levels of the organization. Referring to the analysis of each dimension of organizational culture variables in the previous section, the 7 dimensions only 2 are perceived to be well implemented, namely innovation and 
courage to take risks and attention to detail. This condition is because the company is in a transition stage in adjusting to the application of a new organizational culture after the change of leadership which was held 2 years ago. These changes have been implemented in stages where the management has not finished formulating the new organizational culture guidelines. This is why RTTL.EP does not yet have an organizational culture that matches the vision of the new leadership/board of directors.

The absence of a new organizational culture can hinder the desired changes. According to Kreitner and Kinicki (2008), organizational culture is the shared values and beliefs that underlie corporate identity. Robbins (2013) states that organizational culture is a general perception held by organizational members, a system of shared meaning, which has several functions as follows:

a. Has a distinct role. This means that work culture creates apparent differences between one organization and another;

b. Brings a sense of identity to organizational members;

c. Make it easier for the growth of commitment to something broader than individual self-interest; and

d. Increase the stability of the social system.

About the social aspect, organizational culture serves as the glue that helps unite the organization by providing precise standards for what employees must say and do, which in turn serves as a meaning-making and control mechanism that guides and shapes the attitudes and behavior of employees (Indiyati, 2014,2018).

Given the critical role of organizational culture as a guide for the organization in achieving its goals, RTTL.EP management must immediately complete the process of transforming a new corporate culture.

Based on the results of partial hypothesis testing, which proves that organizational culture has a positive and significant effect on employee performance, the higher the application of organizational culture, the more employee performance will be increased. Based on the results of descriptive data processing, it shows that the implementation of organizational culture has not been maximally implemented, but the contribution to improving employee performance is significant.

This is because of RTTL.EP is currently trying to implement a new organizational culture in line with the leadership change made two years ago. Although the new organizational culture has not yet been compiled into official company documents, in general a policy has been determined to transform the company into a modern company with high competitiveness, including a strategy to improve employee performance, which has started to be realized since early 2020. In this regard, Indiyati $(2014,2018)$, explains that organizational culture is fundamental, which contains beliefs, shared core values, something that is a core characteristic, which is believed and carried out jointly by all members of the organization. In this case, the need to transform and improve performance has been 
understood together as a guideline followed by all RTTL.EP levels from management to employees.

These results indicate the importance of organizational culture on employee performance; if organizational culture can be formulated as a code of conduct and how the company works and is accompanied by internalization that goes well, then employee performance will also increase. Robbins \& Judge (2014), explains that organizational culture has a strong relationship with employee performance, where employees at companies with strong cultures are more committed to showing their best performance compared to employees in companies with weak organizational cultures. Another opinion also states that an organization that changes its organizational culture can improve its performance very significantly compared to an organization that does not make organizational changes and shared values make employees feel comfortable working, have commitment and loyalty and make employees try harder, improve performance and job satisfaction of employees and maintaining competitive advantage (Wibowo, 2016).

Based on the analysis above, it can be understood that organizational culture is a value system that is shared as a guide for all members of the organization in achieving its goals, which is proven to be a factor that has a significant influence on improving employee performance. The results of this study support the results of research by Toyib (2005), Maamari \& Majdalani (2017), and Yiing (2008), which prove that organizational culture has a significant effect on improving employee performance.

\section{Transformational Leadership}

Leadership in an organization is a process for influencing, directing and managing all activities of organizational members in achieving common goals. Leadership is an essential organizational management function that is carried out in the planning, implementation, monitoring and evaluation stages. Without leadership, the organization will not be able to achieve the goals that have been set. This is as stated by Greenberg \& Baron (2016), that leadership is a process in which individuals influence other group members towards achieving defined group or organizational goals.

Each organization has its type and pattern of leadership according to the character of the organization. In general, there are several types and styles of leadership, one of which is transformational leadership, in which to achieve collective goals. The leader unites mutually beneficial motives that the leader and subordinates have to achieve the desired change (Burns, in Yukl, 2001). In this case, the leader inspires followers to go beyond their interests and can have a profound and extraordinary impact on the person of his followers (Ansory et al., 2018).

Based on the descriptive data exposure of respondents' responses to each dimension, it is generally known that the respondent's assessment of the Transformational Leadership variable can be seen from the presentation of the data processing results shown in table 4.2 below: 
Table 2 Recapitulation of Respondents' Responses to Transformational Leadership Variables

\begin{tabular}{|c|l|c|c|c|}
\hline No. & Dimensions & Score & Percentage & Category \\
\hline 1 & Idealized Influence & 1774 & $71.53 \%$ & Effective \\
\hline 2 & Inspirational Motivation & 1622 & $87.20 \%$ & Very Effective \\
\hline 3 & Intellectual Stimulation & 1423 & $76.51 \%$ & Effective \\
\hline 4 & Individual Consideration & 1954 & $78.79 \%$ & Effective \\
\hline \multicolumn{2}{r|}{ Total } & $\mathbf{6 7 7 3}$ & $\mathbf{7 8 . 0 3} \%$ & Effective \\
\hline
\end{tabular}

Source: Questionnaire Data Processing, 2020

These results show that the overall implementation of the transformational leadership style in RTTL.EP is in the high category, meaning that the company's leadership style has been able to unite various individual motives and motivate employees to participate in achieving the general goals of the organization through harmonious, trusting and open reciprocal relationships. Since the change of the board of directors 2 years ago, there has been a change in leadership style from previously tending to use a charismatic approach that relies on leader figures to being more open (democratic) where new leaders try to involve employees to the lowest level to be involved in every policy formulation process. Through a more participatory meeting forum. Besides, current leaders listen more to input from employees under them as material for evaluating company policies.

The implementation of this leadership style can generate employee motivation to complete work optimally, follow the established organizational rules and have the initiative in developing various work methods that are considered more effective in achieving organizational goals.

Transformational leadership style is a leadership character needed by RTTL.EP which is currently working to improve organizational performance in line with the new leadership vision. Related to this, Robbins (2013), points out that the style of transformational leadership is the process whereby a leader who pays attention to the concerns and needs of individual followers; these leaders change followers' awareness of problems by helping them see old problems in new ways, and they inspire and inspire followers to make extra efforts to achieve the group's goals. Umam (2010), further explains that transformational leadership can lead to positive change in subordinates (followers) because not only leaders pay attention and are involved in the process, but also subordinates are focused on helping each group member to be able to achieve new goals successfully.

Thus, through the implementation of a transformational leadership style, it is hoped that all human resources will be actively involved and will make it easier for leaders to direct all their resources to support the new RTTL.EP organizational vision. 


\section{The Influence of Organizational Culture and Transformational Leadership on Employee Performance}

Based on the results of simultaneous hypothesis testing, it can be seen that the effect of Organizational Culture and Transformational Leadership on employee performance together is significant. This explains that the implementation of organizational culture and transformational leadership when applied together has a fundamental role in increasing employee performance improvement at RTTL.EP.

Organizational culture and transformational leadership styles are interrelated with each other because no leader is separated from the organizational culture (Robbins \& Coulter, 2010). The leadership style that is implemented depends on the organizational culture used because organizational culture as a shared value system guides the patterns of interaction, relationships between members, and how to work, including shaping the character and style of leadership in achieving organizational goals. Thus, leadership style is part of the implementation of organizational culture, the higher the leadership quality, the better the perception of each member regarding organizational culture (Sutrisno, 2018).

Organizational culture shapes the patterns and behavior of each member. At the same time, the leadership style is the leader's effort in directing subordinates to work following organizational goals as the results of this study prove that the implementation of organizational culture and transformational leadership styles can improve employee performance. These results support the results of research conducted by Maamari (2017), which proves the simultaneous influence of organizational culture and leadership style on employee performance.

Simultaneous hypothesis testing aims to determine whether there is a significant influence of the Organizational Culture and Transformational Leadership Variables on Employee Performance jointly (simultaneously). The hypothesis proposed is as follows:

$\mathrm{H}_{0}: \beta=0 \rightarrow$ Organizational Culture and Transformational Leadership have no significant effect on employee performance.

$\mathrm{H}_{1}: \beta \neq 0 \rightarrow$ Organizational Culture and Transformational Leadership have a significant effect on Employee Performance.

The criteria for the decision to accept / reject the hypothesis are as follows:

$\mathrm{F}_{\text {count }}>\mathrm{F}_{\text {table }}$ at the $95 \%$ confidence level $(\alpha=0.05)$, then $\mathrm{H}_{0}$ is rejected.

$\mathrm{F}_{\text {count }}<\mathrm{F}_{\text {table }}$ at the $95 \%$ confidence level $(\alpha=0.05)$, then $\mathrm{H}_{0}$ is rejected.

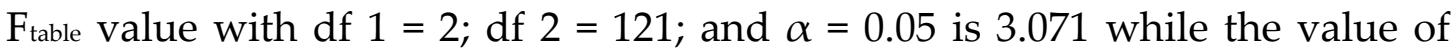
Fcount based on the results of processing using SPSS software version 24 can be seen in the following ANOVA table: 
Table 3 Simultaneous Hypothesis Test Results

\begin{tabular}{|c|l|r|r|r|r|r|}
\hline \multicolumn{7}{|c|}{ ANOVA $^{\mathrm{a}}$} \\
\hline \multirow{3}{*}{1} & Sodel & Sum of Squares & $\mathrm{df}$ & Mean Square & F & \multicolumn{1}{c|}{ Sig. } \\
\hline \multirow{2}{*}{1} & Regression & 3046,041 & 2 & 1523,020 & 80,637 &, $000^{\mathrm{b}}$ \\
\cline { 2 - 8 } & Residual & 2285,378 & 121 & 18,887 & & \\
\cline { 2 - 8 } & Total & 5331,419 & 123 & & & \\
\hline
\end{tabular}

a. Dependent Variable: Performances

b. Predictors: (Constant), Transformational Leadership Style, Organizational Culture

The simultaneous hypothesis test results are shown in table 4:26 showing the value of $F_{\text {count }}$ with $\mathrm{df} 1=2$ and $\mathrm{df} 2=121$ is $=80.637$ with a significance of 0.000 . Testing by comparing sig $=0,000<\alpha=0.05$, then $\mathrm{H}_{0}$ is rejected, as well as testing through the comparison of the value of $\mathrm{F}_{\text {count }}=80.637>\mathrm{F}_{\text {table }}=3.071$, also rejecting $\mathrm{H}_{0}$.

Based on the test results, it can be concluded that together there is a significant influence of the Organizational Culture and Transformational Leadership variables on Employee Performance. These results also indicate that the regression model is fit (suitable) to explain the employee performance variable.

Partial test or $t$ test is done by comparing the value of $t$ count with $t$ table with the following hypotheses:

$\mathrm{H}_{0}: \beta_{1}=0$, there is no significant effect partially.

$H_{1}: \beta_{1} \neq 0$, there is no significant effect partially.

The criteria for the decision to accept / reject the hypothesis are as follows:

$t_{\text {count }}<t_{\text {table }}$ at $95 \%$ confidence level $(\alpha=0,05)$, then H0 is accepted.

$t_{\text {count }}>t_{\text {table }}$ at $95 \%$ confidence level $(\alpha=0,05)$, then $\mathrm{H} 0$ is rejected.

The table value with a significance level $(\alpha)$ of 0.05 with $\mathrm{df}=121$, is 1.980 . The $t_{\text {count }}$ value can be determined based on the results of the partial test ( $t$ test) which is shown in the following table:

Table 4 Partial Hypothesis Test Results

\begin{tabular}{|c|c|c|c|c|c|c|}
\hline \multicolumn{7}{|c|}{ Coefficients $^{\mathrm{a}}$} \\
\hline & \multirow[t]{2}{*}{ Model } & \multicolumn{2}{|c|}{$\begin{array}{c}\text { Unstandardized } \\
\text { Coefficients }\end{array}$} & \multirow{3}{*}{$\begin{array}{c}\begin{array}{c}\text { Standardized } \\
\text { Coefficients }\end{array} \\
\text { Beta } \\
\end{array}$} & \multirow[b]{3}{*}{7824} & \multirow[t]{2}{*}{ Sig. } \\
\hline & & B & Std. Error & & & \\
\hline \multirow[t]{3}{*}{1} & (Constant) & 24,291 & 3,105 & & & ,000 \\
\hline & Organizational culture & 111 & ,045 & , 187 & 2,457 & ,015 \\
\hline & $\begin{array}{l}\text { Transformational } \\
\text { Leadership Style }\end{array}$ & ,585 & ,071 & ,626 & 8,233 & 000 \\
\hline
\end{tabular}

a. Dependent Variable: Performances

Based on the results of the partial hypothesis test shown in table 4.4 above, it can be interpreted as follows:

a. The influence of organizational culture variables on employee performance has a value of $t=2.457$ with a significance of 0.015 . Because the value of $t$ is greater than $\mathrm{t}$ table $(2.457>1.980)$, then $\mathrm{H}_{0}$ is rejected and $\mathrm{H}_{1}$ is accepted, meaning that there is a significant influence of the Organizational Culture Variable on Employee Performance. 
b. The Influence of Transformational Leadership Variables on Employee Performance has a value of $t=8.233$ with a significance of 0.000 . Because the value of $t$ is greater than $t$ table $(8,233>1,980)$, then $H_{0}$ is rejected and $H_{1}$ is accepted, meaning that there is a significant influence of Transformational Leadership Variables on Employee Performance.

\section{E. CONCLUSION}

The implementation of organizational culture is in a sufficient category, which means that the organizational culture has not been fully implemented as a guide for all employees at work. The dimension of Organizational Culture that is perceived as the highest is attention to detail, while the lowest dimension is stability. Simultaneously, organizational culture is proven to have a significant effect on improving employee performance. The implementation of transformational leadership is in the high category, which means the leader has been able to apply a transformational leadership style in directing employees according to company goals. The highest dimension perceived is Inspirational Motivation, while the lowest dimension is Idealized Influence.

\section{REFERENCES}

1. Abdolmohammadi, M. J. (2005). The Components of Intellectual Capital for Accounting Measurement. Retrieved from http://www.sbaer.lka.edu/research/1999/wdsi/99wds.024.htm

2. Ahmadi, F., Parivizi, B., \& Meyhami, B. (2001). Intellectual capital accounting and its role in creating competitive advantage at the universities. VIRTUAL, 1(1), 894-912.

3. Alvesson, M. (2012). Understanding organizational culture. Sage.

4. Amiri, A. N., Jandghi, G., Alvani, S. M., Hosnavi, R., \& Ramezan, M. (2010). Increasing the intellectual capital in organization: Examining the role of organizational learning. European Journal of Social Sciences, 14(1), 98-108.

5. Ansory, Al Fadjar, \& Meithiania. (2018). Manajemen Sumber Daya Manusia. Sidoarjo: Indomedia Pustaka.

6. Barney, J. B. (2014). Gaining and Sustaining Competitive Advantage. Pearson Higher Ed.

7. Barney, J. B. \& Hansen, M. H. (2002). Trustworthiness as a source of competitive advantage. Strategic Management Journal, 15(1), 175-190.

8. Bontis, N. (1998). Intellectual capital: an exploratory study that develops measures and models. Management Decision, 36(2), 6376. https://doi.org/10.1108/00251749810204142

9. Brooking, A. (1996). Intellectual capital: Core Asset for the Third Millennium Enterprise, International Thomson Business Press, London. Management Journal, 17(4). 
10. Behery, M., Papanastassiou, M., \& Ajmal, M. (2014). Examining the Relationship between Organizational Culture and Knowledge Management: The Moderation Effect of Organizational Divisions at an Abu Dhabi Gas Company. SAM Advanced Management Journal, 49.

11. Carlucci, D., Marr, B., \& Schiuma, G. (2004). The knowledge value chain: how intellectual capital impacts on business performance. International Journal of Technology Management, 27(6-7), 575-590.

12. Creswell, J. W \& Creswell, J. D. (2018). Research Design. California: SAGE Publications.

13. Chen, C. J., \& Huang, J. W. (2007). How Organizational Climate and Structure Affect Knowledge Management: The Social Interaction Perspective. International journal of information management, 27(2), 104-118.

14. Collis, D. J., \& Montgomery, C. A. (1995). Competing on Resources: Strategy in the 1990s. Knowledge and strategy, 73(4), 25-40.

15. Colquitt, J., LePine, J. A., \& Wesson, M. J. (2018). MGMT 363: Organizational Behavior. McGraw-Hill Education Create.

16. Greenberg, J., \& Baron, R. A. (2000). Behavior in Organization: Managing the Human Side Work. Upper Saddle River, NJ: Prentice Hall.

17. Indrawati, P. D. (2015). Metode Penelitian Manajemen dan Bisnis Konvergensi Teknologi Komunikasi dan Informasi. Bandung: Refika Aditama.

18. Indiyati, D. (2014). Pengaruh Budaya Organisasi, Disiplin Kerja Terhadap Kepuasan Kerja dan Dampaknya Terhadap Produktivitas Kerja Pegawai Pada Dinas Koperasi Usaha Mikro Kecil Menengah dan Perindustrian Kabupaten Ngawi. eAbstract Excellent, 1(2), 23-35.

19. Indiyati, D. (2018). The Role of Organisational Culture, Intellectual Capital and Competitive Advantage in Supporting the Government Policies in Education. International Journal of Economic Policy in Emerging Economies, 11(1-2), 68-82.

20. Kimsey-House, K., \& Kimsey-House, H. (2015). Co-active leadership: five ways to lead. Berrett-Koehler Publishers.

21. Kinicki, A., \& Kreitner, R. (2008). Organizational Behavior. New York: McGrawHill.

22. Linnenluecke, M. K., \& Griffiths, A. (2010). Corporate sustainability and organizational culture. Journal of World Business, 45(4), 357-366.

23. Maamari, B. E., \& Majdalani, J. F. (2017). Emotional intelligence, leadership style, and organizational climate. International Journal of Organizational Analysis, 25(2), 327-345. https://doi.org/10.1108/IJOA-04-2016-1010

24. Meek, V. L. (1988). Organizational culture: Origins and weaknesses. Organization Studies, 9(4), 453-473.

25. Ojo, O. (2009). Impact assessment of corporate culture on employee job performance. Business Intelligence Journal, 2(2), 388-397. 
26. Oktania, I. N. (2014). Pengaruh Disiplin Kerja Terhadap Produktivitas Kerja Pegawai di Sub Bagian Umum dan Kepegawaian Dinas Pendidikan Kota Bandung (Doctoral dissertation, Universitas Pendidikan Indonesia).

27. Rahadi, D. R. (2010). Manajemen Kinerja Sumber Daya Manusia. Malang: Tunggal Mandiri Publishing.

28. Rivai, M., \& Basri, A. (2004). Manajemen Kinerja. Yogyakarta: BPFE.

29. Robbins, S. P., \& Judge, T. A. (2014). Organizational behavior: Student value edition. Prentice-Hall.

30. Robbins, S., Judge, T., Millett, B., \& Boyle, M. (2013). Organizational behavior. Frenchs Forest.

31. Schein, E. H. (1990). Organizational culture (Vol. 45, No. 2, p. 109). American Psychological Association.

32. Soomro, B. A., Shah, N., \& Mangi, S. (2019). Factors Affecting the Entrepreneurial Leadership in Small- and Medium-Sized Enterprises (SMEs) of Pakistan: An Empirical Evidence. World Journal of Entrepreneurship, Management and Sustainable Development, 15(1), 31-44. https://doi.org/10.1108/WJEMSD-052018-0054

33. Suliyanto. (2006). Metode Riset Bisnis. Yogyakarta: Andi Offset.

34. Sutrisno, E. (2010). Budaya Organisasi. Jakarta: Kencana Prenada Media Group.

35. Sutrisno, H. E. (2019). Budaya organisasi. Jakarta: Prenada Media.

36. Thoyib, A. (2005). Hubungan Kepemimpinan, Budaya, Strategi, dan Kinerja: Pendekatan Konsep. Jurnal manajemen dan kewirausahaan, 7(1), 60-73.

37. Yukl, G. (2008). How Leaders Influence Organizational Effectiveness. The Leadership Quarterly, 19(6), 708-722. 